\title{
GEOMETRIC SHAPE AND FORCE REQUIRED TO RUPTURE WATERMELON SEED (Colocynthis citrullus)
}

\author{
M. A. Mosallam*, A. K. Zaalouk* and R. A. Werby**
}

\begin{abstract}
This research aims to studying the geometric shape of watermelon seeds (Colocynthis citrullus) and force required to rupture these seeds under different moisture levels and at two orientations of the seed (axis of symmetry of the seed is vertical and horizontal). A geometric shape of the seed was suggested to compare between calculated volume of the seed according to this suggestion and its actual volume showed that calculated volume is reliable. The study showed that within the range of moisture content of the tested seeds, the force required to rupture the seed decreases as moisture content increases and magnitude of this force is higher when this axis of symmetry of the seed subjected to this force is vertical. The greatest rupture force (seed axis of symmetry is vertical) is $57.2 \mathrm{~N}$ and is $47 \mathrm{~N}$ when axis is horizontal.
\end{abstract}

\section{INTRODUCTION}

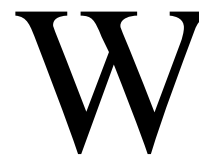
atermelon seed (Colocynthis citrullus) is oil seed, which contains approximately $50 \%$ by weight oil, $28.4 \%$ proteins, 2.7\% fiber, 3.6\% ash and 8.2 carbohydrates (Oyenuga and Fetuga, 1975). The seed is also a good source of essential amino acids. In Egypt, the total cultivated watermelon area is about 174407 feddan, which produces 101013 tons with an average yield of $579 \mathrm{~kg} /$ feddan ( Ministry of Agriculture and Reclamation. 2009). The knowledge of fracture resistance of the seed under external loading would be valuable information in rational design and operation of dehulling machinery, thereby also in improving the dehulling efficiency by proper conditioning of the seed (Shutter and Das, 1997 ; Das and Gupta, 2000). Determination of the geometric shape of the seed enables the determination of its volume and surface area which in turn is valuable in the designing of dehulling machines.

\footnotetext{
* Assoc. Prof., Agr. Eng. Dept., Fac. of Agr., Al-Azhar Univ., Cairo.

** Lect., Agr. Eng. Dept., Fac. of Agr., Al-Azhar Univ., Cairo.
} 
This research aims at investigating the geometric shape and force required to rapture the seed of watermelon to be used as basic data for seed extraction and other process purposes.

\section{REVIEW OF LITERATURE}

Tavakoli et al. (2009) reported quasi statically loaded barley grains in horizontal and vertical orientations with the moisture content at four levels: $7.34,12.11,16.82$, and $21.58 \%$ dry basis. They found that the force required for initiating the grain rupture decreased from 161.97 to $93.94 \mathrm{~N}$ and from 75.37 to $50.16 \mathrm{~N}$, for horizontal and vertical orientations, respectively, with the increase in the moisture content from $7.3421 .58 \%$ dry basis. Burubai et al. (2008) mentioned that the force required to initiate African nutmeg seeds rupture, under quasi-static compressive tests, decreased as moisture content increased from 8.0 to $28.7 \%(\mathrm{db})$. They added that, African nutmegs loaded in the axial position consistently developed seed rupture at lower magnitudes of force $(53.8 \mathrm{~N}$ at 8.0 percent moisture content and $33.1 \mathrm{~N}$ at 28.7 percent moisture content) than those loaded in the lateral positions $(629.6 \mathrm{~N}$ at 8.0 percent moisture content and $112.3 \mathrm{~N}$ at 28.7 percent moisture content. The results given by Saiedirad et al. (2007), showed that the force required for initiating cumin seed rupture decreased from 15.7 to $11.96 \mathrm{~N}$ and 58.2 to $28.8 \mathrm{~N}$, with increase in moisture content from $5.7 \%$ to $15 \%$ d.b., for vertical and horizontal orientations, respectively. Zaalouk et al. (2005) found that the forces required to break each of three verities of bean (Cotender, Bronco and Nbrasic) were 72.1, 97.6 and 11.7 respectively. Dasl and Gupta (2000) found that the force required for sunflower seed rupture decreased as moisture content increased from $4 \%$ to $2 \%$ d.b. and seeds loaded in the horizontal orientation developed cracks at a lower level of force than those loaded in the vertical orientation. They mentioned that the compressive force required to rupture the seeds ranged from 65.2 to $35.3 \mathrm{~N}$ in both orientations. They added that the maximum deformations of the seed at rupture were 1.34 and $1.46 \mathrm{~mm}$ under horizontal and vertical loading orientations, respectively. Suthar and Das (1979) subjected karingda seeds at various moisture contents to quasi-static compressive loading under longitudinal and transverse orientations. Their results showed that, for both orientations, the rupture force of the seed and the corresponding deformation individually followed quadratic relationship with respect to 
moisture content. At any moisture content of the seed tested between 3\% and $19(\mathrm{db})$, the seed rupture force was more in the vertical than the horizontal orientation with peak values of 107 and $77 \mathrm{~N}$ at $11 \%(\mathrm{db})$ respectively. They added that the maximum deformations of the seeds at rupture were 1.52 (vertical) and $1.08 \mathrm{~mm}$ (horizontal).

\section{MATERIALS AND METHODS}

Frequency distribution of watermelon seeds shape:

The ratio of length "L" to width "W" of the seed (Shape index) describes the seed as a solid: lower shape index means more elongated seed and vice versa. 100 malleable seeds were chosen at random. Length and width of each seed were measured and shape index of the seed was calculated. To determine the shape index of most of the seeds gather frequency distribution of these 100 seeds was drawn.

Geometric Shape of watermelon seed:

Figs. (1) and (2) show a picture and two projections of the watermelon seed. To describe the geometric shape of the watermelon seed, the following assumptions were considered:

1- The seed is composed of a main mass about which a ring is attached.

2- The main mass as a solid is considered as a right prism whose base is an ellipse, the lengths of its two semi axes are $a_{1}$ and $b_{1}$.

" $\mathrm{T}_{\mathrm{m}}$ " is the mean of three thicknesses:

i- $\mathrm{T}_{1}$ : Thickness of the seed at its narrow end.

ii- $\mathrm{T}_{2}$ : Greatest thickness of the seed (thickness of the seed at its minor axis). iii- $\mathrm{T}_{3}$ : Thickness of the seed at its broad end

$$
\mathrm{T}_{\mathrm{m}}=\left(\mathrm{T}_{1}+\mathrm{T}_{2}+\mathrm{T}_{3}\right) / 3
$$

3- The ring as a solid is considered as an ellipsoid ring, the lengths of its two semi axes (major and minor) are "a and b" respectively and whose thickness is " $T_{1}$ ".

4- Together, the main mass and the ring forms mass of the seed,

$$
\text { Mass of the seed }=\text { the main mass }+ \text { the ring mass. }
$$

5- Area of the ellipse of two major and minor semi axes of lengths of "a and b" respectively is (Larson and Hostetler, 2001):

$$
\begin{gathered}
\text { Area }=\pi \mathrm{a} b \\
\text { Circumference }=2 \pi \sqrt{\frac{a^{2}+b^{2}}{2}}
\end{gathered}
$$




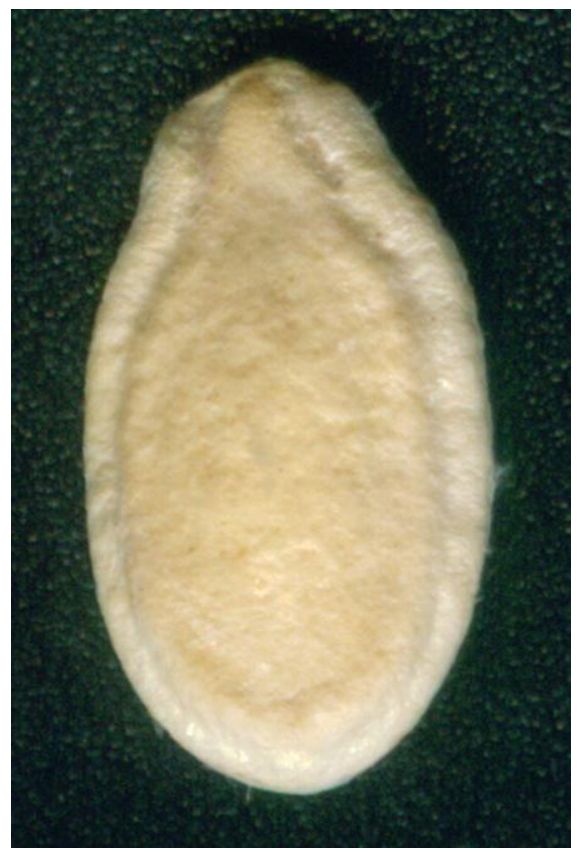

Fig(1): Watermelon seed.
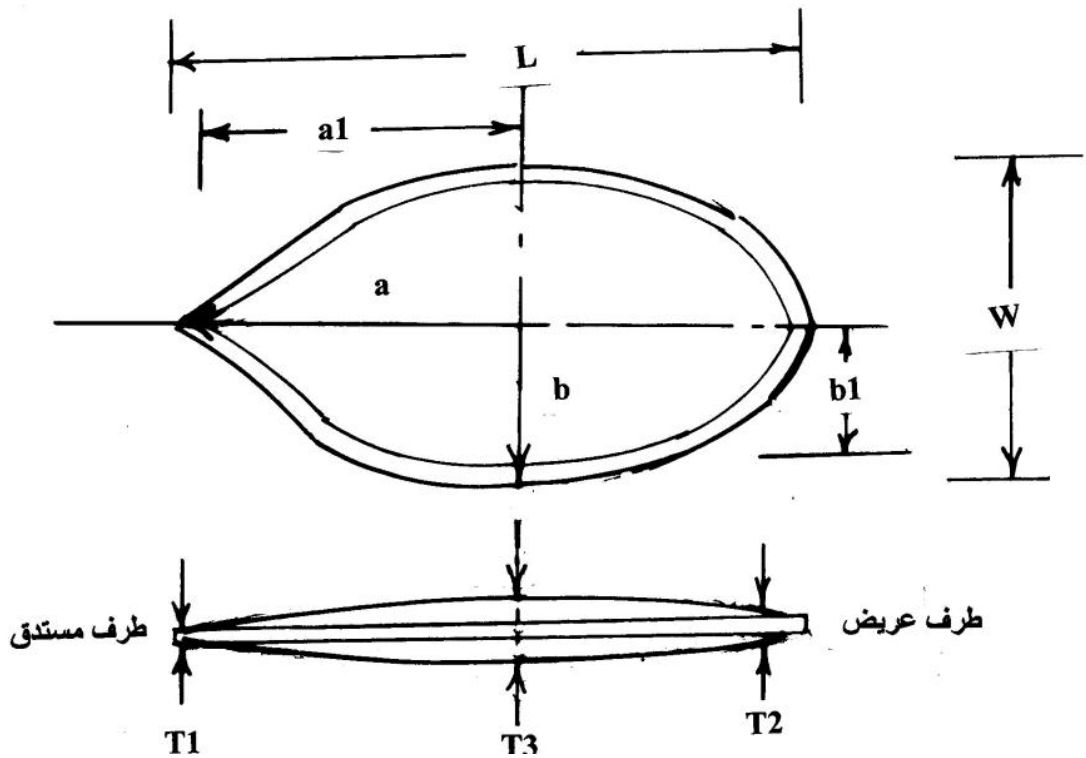

Fig.(2): Projection of a watermelon seed (the elevation is not drawn to a scale).

L, W: length and width; a, b: major and minor semi axes; a1, b1: major and minor semi axes of the inner ellipse (main mass of the seed); T1, T2, T3: thicknesses. 
Volume of an ellipsoid prism of height (thickness) "T":

$$
\text { Volume }=\pi \text { a b T }
$$

Area of the projection of the ring $=$

$$
\left(\pi \mathrm{ab}-\pi \mathrm{a}_{1} \mathrm{~b}_{1}\right)=\pi\left(\mathrm{ab}-\mathrm{a}_{1} \mathrm{~b}_{1}\right)
$$

Volume of the ring $=$

$$
\left(\pi \mathrm{ab}-\pi \mathrm{a}_{1} \mathrm{~b}_{1}\right) \times \mathrm{T}_{1}=\pi\left(\mathrm{ab}-\mathrm{a}_{1} \mathrm{~b}_{1}\right) \times \mathrm{T}_{1}
$$

Area of the projection of the main mass $=\pi a_{1} b_{1}$

$$
\text { Volume of the main mass }=\pi \mathrm{a}_{1} \mathrm{~b}_{1} \times \mathrm{T}_{\mathrm{m}}
$$

Volume of the seed $=$ volume of the main mass + volume of the ring

$$
=\pi\left(\mathrm{ab}-\mathrm{a}_{1} \mathrm{~b}_{1}\right) \times \mathrm{T}_{1}+\pi \mathrm{a}_{1} \mathrm{~b}_{1} \times \mathrm{T}_{\mathrm{m}}
$$

Lateral surface area of the ring may be calculated as:

$$
2 \pi \sqrt{\frac{a^{2}+b^{2}}{2}} \times \mathrm{T}_{\mathrm{m}}
$$

Surface area of the seed may be calculated as:

$$
2 \pi \mathrm{ab}+2 \pi \sqrt{\frac{a^{2}+b^{2}}{2}} \times \mathrm{T}_{\mathrm{m}}
$$

The calculated volume according to eq. (9) was compared to the actual volume of the seed determined by weight of the displaced water by the seed according to Mohsenin (1970). For this reason, 50 uniform seeds were chosen at random and the required dimensions to calculate the volume of the seed were measured using a caliper of accuracy of $0.1 \mathrm{~mm}$. The differences $(\mathrm{a}-\mathrm{a} 1)$ and $(\mathrm{b}-\mathrm{b} 1)$ are taken by the naked eye to be 1 $\mathrm{mm}$ for seed. Weight of the displaced water by each seed was measured using a balance of accuracy of $0.0001 \mathrm{mg}$.

Force required to rupture the seeds vertically and horizontally at four moisture contents:

Four levels of moisture content of the seeds were determined as follows: some seeds were taken from a seed storage. These seeds were divided into four groups. About $20 \mathrm{~g}$ of seeds of each group were soaked in water for time intervals of: 0.0 (no soaking in water), $0.5,1.0$ and $1.5 \mathrm{~h}$. then 
moisture content of each group was determined by drying the seeds under $105^{\circ} \mathrm{C}$ for $24 \mathrm{~h}$. The moisture contents " $\mathrm{MC}$ " of the four groups ( $\mathrm{MC} 1, \ldots$, MC4) were found to be: 9.64, 13.84, 16.30 and 21.03\% d.b. respectively. $\mathrm{MC1}$ is seed moisture content under storage. After the previously mentioned four times of soaking (0.0, 0.5, 1.0 and $1.5 \mathrm{~h}), 20$ uniform seeds were chosen at random from each soaked group of seeds and subjected to the rupture force test. The test was carried out using the apparatus designed by Zaalouk and Ghanem (2003), Fig.(3), after modifying it by fixing a plate at the head of its plunger to adapt it to fracture a seed of watermelon. Force " $F$ " of a digital force gauge (of magnitude of $2200 \mathrm{~g}$ ) was magnified using a lever to produce the force required to rupture the seed. Weight of the left side of the lever, fig.(3), was taken into consideration when calculating the required rupture force. From each 20 chosen seeds from each soaked group, 10 seeds with their longitudinal axis of symmetry vertical were subjected to the vertical force of the plunger of the apparatus (vertical rupture force " $F_{v}$ ") while the other 10 seeds were subjected to the force of the plunger (horizontal rupture force " $\mathrm{F}_{\mathrm{h}}$ ") while longitudinal axis of symmetry of each is horizontal. The seeds were subjected to the plunger force till sound of a crack (rupture) is heard and the rupture force for each seed were calculated according to Zaalouk and Ghanem (2003) and recorded. The force required to rupture watermelon seeds under each of the previously mentioned four levels of moisture and each of the two orientations of the seed while subjected to the rupture force (vertical and horizontal) was considered as the mean of 10 tested seeds.

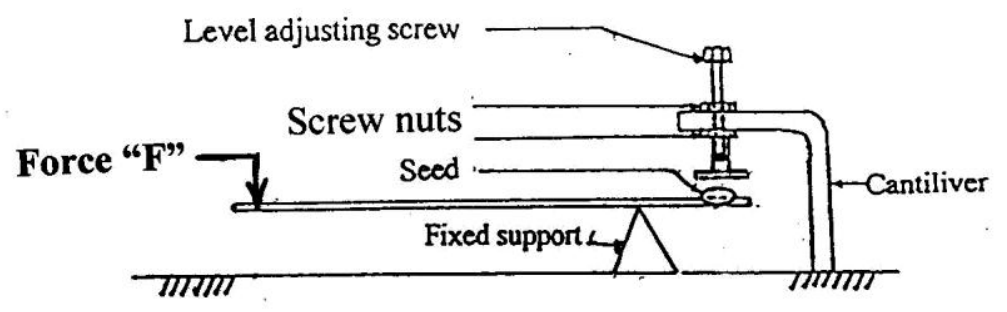

Fig.(3): Apparatus used for fracturing the seed, Zaalouk and Ghanem (2003). 


\section{RESULTS AND DISCUSSION}

Frequency destitution of watermelon seeds shape:

Fig.(4) shows the frequency distribution with respect to shape index for the chosen 100 seed. The distribution shows that the greatest frequency is of the shape index of range 0.560 to 0.574 .

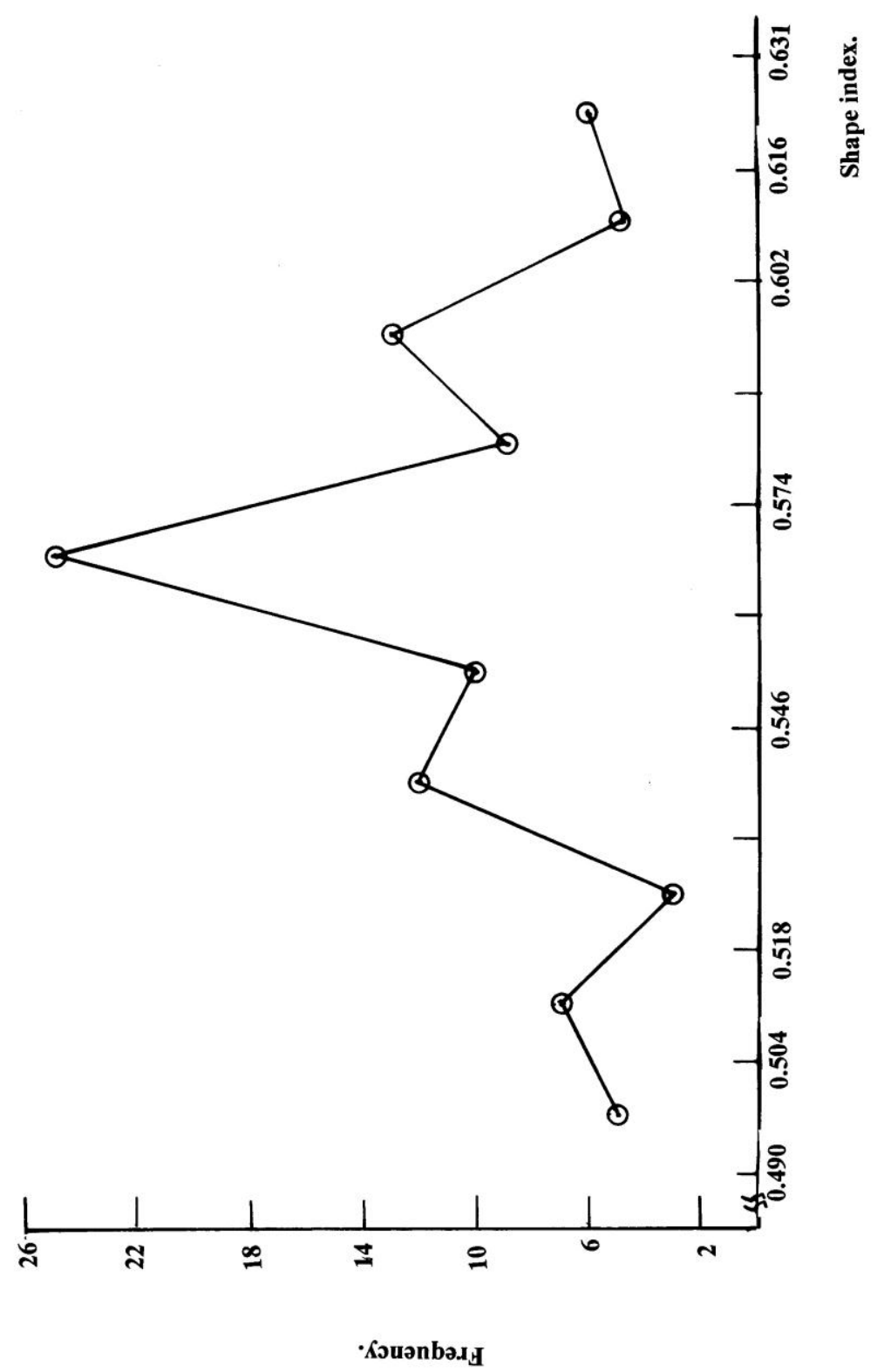

Fig.(4): Frequency distribution of the shape index. 
Geometric Shape of watermelon seed:

Fig.(5) shows the relation between actual volumes (according to weight of displaced water) of 50 malleable, randomly chosen seeds and calculated volumes according to eq.(9).

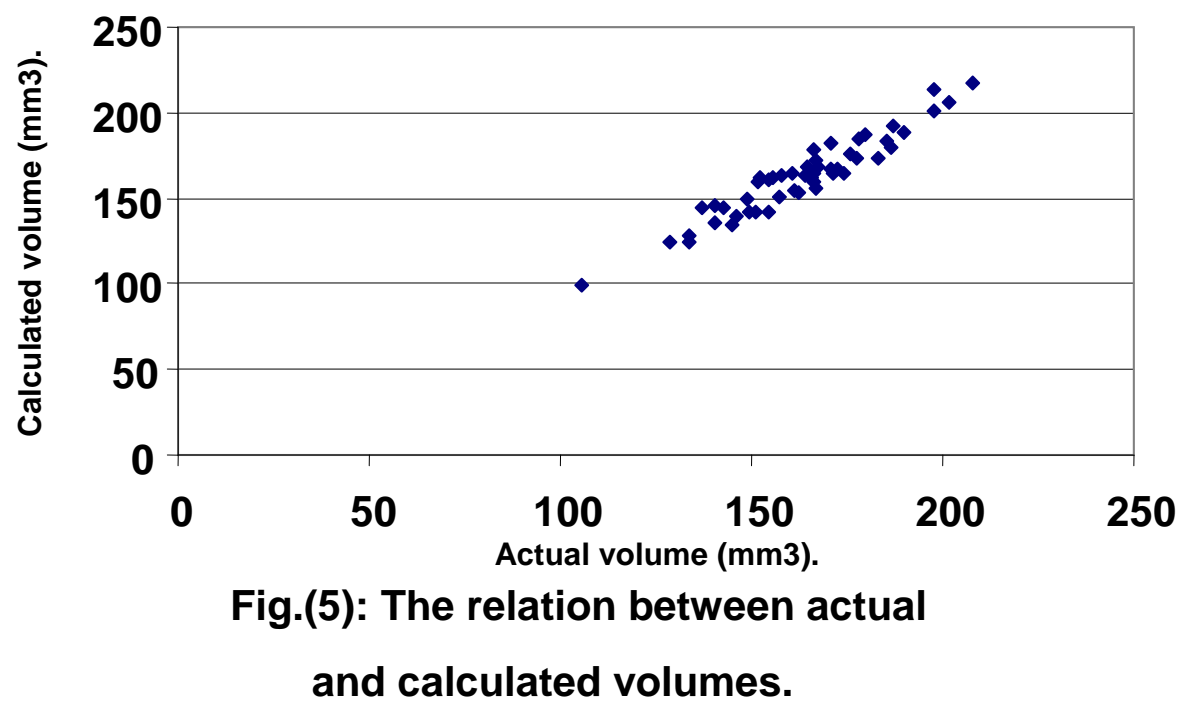

If the values of the two volumes are identical, then the curve of Fig.(5) must be a perfect line of slope one and this line passes through the origin. To compare between calculated and actual volumes ( $\mathrm{Vc}$ and $\mathrm{Va}$ ), the following ratio "I" was calculated (as a percent) for each seed:

$$
\mathrm{I}=(\mathrm{Va}-\mathrm{Vc}) / \mathrm{Va}
$$

This expression "I" relates the difference between actual and calculated volume to the actual volume. The mean value of $\mathrm{I}$ is $3.9 \%$ which means that equation (9) can be relied on for calculating volume of the seed. A subsequent work is required to determine the possibility of applying eq.(11) for calculating surface area of the seed. For calculating volume according to eq.(9) and calculating surface area according to eq.(11), a computer program was designed, using visual basic 6 , to carry out such a job. The code of the program is given at the appendix.

Force required to rupture the seeds vertically and horizontally at four moisture contents:

Fig.(6) shows the relation between moisture content of the seed and force required to rupture the seed while seed axis of symmetry is vertical (Fv) 
and force required to rupture the seed while seed axis of symmetry is horizontal (Fh). From fig.(6), it can be concluded that:

1- As moisture content of the seed increases, rupture force decreases.

2- Force required to rupture the seed, at same moisture content, is greater when axis of symmetry, subjected to the force, is vertical.

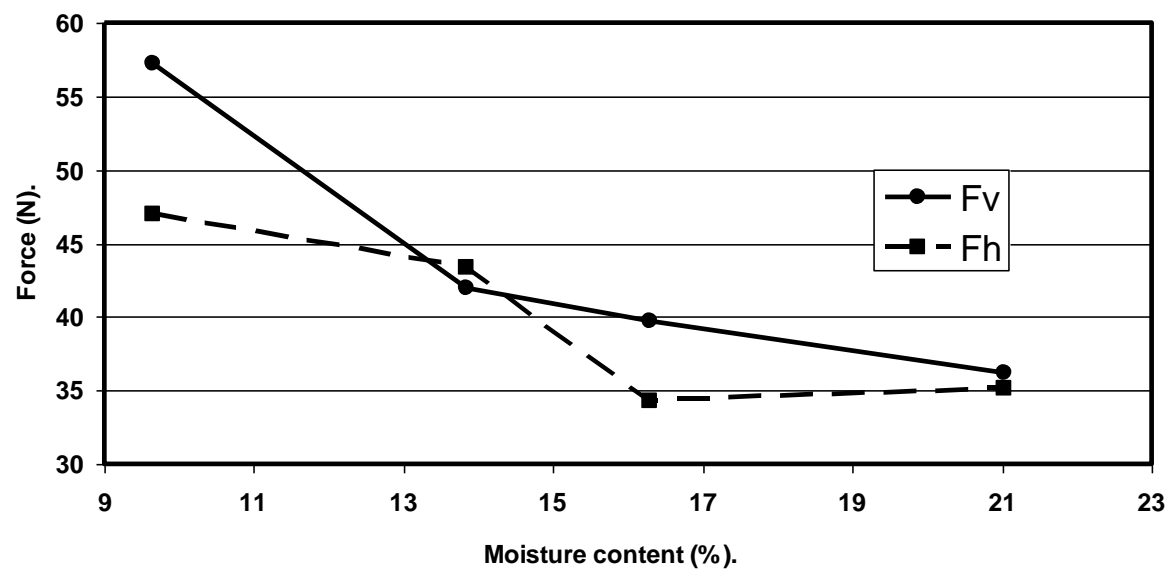

Fig(6): The relation between moisture content and each of vertical "Fv" and horizontal "Fh" rupture forcec.

3- At moisture content of $21 \%$, the two rupture forces ( $\mathrm{Fv}$ and $\mathrm{Fh}$ ) approaches each other.

Tables (1 and 2) show the rupture force, seed deformation and shape index at each of the four levels of moisture content for each of the two orientations of the seed (vertical and horizontal axes of symmetry respectively. These two tables show that: for a range of seed moisture content of 9.6 to $21 \%(\mathrm{db})$, the maximum required force to rupture the seed while its axis of symmetry is vertical is $57.2 \mathrm{~N}$ while the maximum force when axis of symmetry of the seed horizontal is $47 \mathrm{~N}$. For the same range of moisture content, the minimum required force to rupture the seed while its axis of symmetry is vertical is $36.2 \mathrm{~N}$ while the maximum force when axis of symmetry of the seed horizontal is $36.1 \mathrm{~N}$. 
Table (1): Force required to rupture the seed when seed axis of symmetry is vertical- (Fv), Deformation of the seed (D), Shape index (I), at four levels of moisture content (MC).

\begin{tabular}{|c|c|c|c|}
\hline \multicolumn{4}{|c|}{ Fv } \\
\hline & $\mathrm{F}(\mathrm{N})$ & $\mathrm{D}(\mathrm{mm})$ & $\mathrm{SI}(\%)$ \\
\hline \multicolumn{4}{|c|}{ MC1 = 9.6 (\% db) } \\
\hline Mean & 57.2 & 2.03 & 0.57 \\
\hline CV (\%) & 17.1 & 46.3 & 11 \\
\hline \multicolumn{4}{|c|}{ MC2 = 13.8 (\%db) } \\
\hline Mean & 42 & 1.57 & 0.56 \\
\hline CV (\%) & 14.3 & 42.7 & 5.2 \\
\hline \multicolumn{4}{|c|}{ MC3 = 16.3 (\%db) } \\
\hline Mean & 39.7 & 1.48 & 0.56 \\
\hline CV (\%) & 7.1 & 62.2 & 7.1 \\
\hline \multicolumn{4}{|c|}{ MC4 = 21 (\% db) } \\
\hline Mean & 36.2 & 1.89 & 0.59 \\
\hline CV (\%) & 8.1 & 68.4 & 5.2 \\
\hline
\end{tabular}

Table (2): Force required to rupture the seed when seed axis of symmetry is horizontal- (Fv), Deformation of the seed (D), Shape index (I), at four levels of moisture content (MC).

\begin{tabular}{|c|c|c|c|}
\hline \multicolumn{4}{|c|}{ Fh } \\
\hline & $\mathrm{F}(\mathrm{N})$ & $\mathrm{D}(\mathrm{mm})$ & $\mathrm{SI}(\%)$ \\
\hline \multicolumn{4}{|c|}{ MC1 = $9.6(\% \mathrm{db})$} \\
\hline Mean & 47 & 0.58 & 0.57 \\
\hline $\mathrm{CV}(\%)$ & 23.8 & 79.3 & 5.3 \\
\hline \multicolumn{4}{|c|}{ MC2 = $13.8(\% \mathrm{db})$} \\
\hline Mean & 43.4 & 0.57 & 0.56 \\
\hline CV (\%) & 23.7 & 61.1 & 5.4 \\
\hline \multicolumn{4}{|c|}{ MC3 = $16.3(\% d b)$} \\
\hline Mean & 34.3 & 0.76 & 0.56 \\
\hline CV (\%) & 13.7 & 46.1 & 7.1 \\
\hline \multicolumn{4}{|c|}{ MC4 = $21(\% \mathrm{db})$} \\
\hline Mean & 35.1 & 0.46 & 0.57 \\
\hline CV (\%) & 13.1 & 62.2 & 3.5 \\
\hline
\end{tabular}




\section{SUMMARY}

This research aims to study the geometric shape of watermelon seeds (Colocynthis citrullus) and force required to rupture these seeds under different levels of its moisture. The seed is considered in its main mass as an ellipsoid and this ellipsoid is surrounded by an elliptical ring. Volume and area of the seed were calculated according to this assumption and calculated volume was compared to the actual volume of the seed determined by water displacement. Width to length of the seed was considered as a factor which gives an idea of the shape of the seed. A frequency distribution was carried out for 100 uniform and randomly chosen seed to investigate the shape index which has the greatest distribution. Under 4 levels of seed moisture content (9.6, 13.8, 16.3 and $21 \% \mathrm{db}$ ), the force required to rupture while in two orientations: axes of symmetry of the seed were vertical and horizontal. The relation between moisture content and rupture force was determined in each case.

The study concluded to the following:

1- The suggested geometric shape of the seed is reliable in calculating volume of the seed and calculating surface area of the seed for needs of subsequent work. The difference between calculated volume of the seed (according to volume relation from the suggested geometric shape) and actual volume with respect to actual volume was $3.9 \%$.

2- This research showed that the greatest frequency of shape factor of the seeds may be in the range of the shape factor of 0.560 to 0.574 .

3 - The study showed that, within the range of moisture content of the used seeds, the force required to rupture the seed decreases as moisture content increases and magnitude of this force is higher when axis of symmetry of the seed subjected to this force is vertical. The greatest rupture force (seed axis of symmetry is vertical) is $57.2 \mathrm{~N}$ and the greatest rupture force (seed axis of symmetry is horiznotal) is $47 \mathrm{~N}$.

\section{REFERANCES}

Oyenuga V. A. and B. A. Fetuga (1975). Some aspects of biochemistry and nutritional value of watermelon. J. of Sci. of Food and Ag. 26(6): $843-854$. 
Suthar S. H. and S. K. Das (1998). Fracture resistance of karingda (Citrullus lanatus) seeds to compressive loading. J. Food Eng. 34: $77-90$.

Das S. K. and R. K. Gupta (2000). Fracture resistance of sunflower seed and kernal to compressive loading. J. Food Eng. 46(1): $1-8$.

Tavakoli H., S.S. Mohtasebi, A. Rajabipour and M. Tavakoli (2009). Effects of moisture content, loading rate, and grain orientation on fracture resistance of barley grain. RES. AGR. ENG. 55(3): $85-$ 93.

Brubai W., A. J. Akor, A. H. Igoni and Y. T. Puyate (2008). Fracture resistance of African nutmeg (Monodora myristica) to compressive loading. Am.-Eurasian J. of Sci. Res. 3(1): 15 - 18.

Saiedirad M. H., A. Tabatabaeefar, A. Borghei, M. Mirsalehi, F. Badi and M. G. Varnamkhasti (2007). Effects of moisture content, seed size, loading rate and seed orientation on force and energy required for fracturing cumin seed (Cuminum cyminum ) under quasi-static loading. J. Food Eng. 86: $565-572$.

Zaalouk A. K., M. A. Mosallam, A. A. El-Meseery (2005). Some physical and mechanical properties of been seeds. Misr J. Ag. Eng. 22(3): $1041-1058$.

Larson R. and R. P. Hostetler (2001). College Algebra. Hought Co., USA. App.:127.

Zaalouk A. K. and T. H. Ghanem (2003). Some physical and mechanical properties of cowpea seeds. Misr J. Ag. Eng. 20(2): 363 - 379.

Mohsenin N. N. (1970). Physical properties of plant and animalmaterials. Gordon and esearch science publishers . Volume 1: $66-67$.

\section{APPENDIX}

Code of the computer program to calculate volume and surface area of the seed:

Private Sub cmdCalculate_Click()

Dim A

$A=\operatorname{Val}(t x t 2 A \cdot T e x t)$

$\operatorname{Dim} \mathrm{x}$

$\mathrm{x}=\mathrm{A} / 2$ 
Dim M

$\mathrm{M}=\mathrm{x}-1$

Dim B

$\mathrm{B}=\operatorname{Val}(\operatorname{txt} 2 \mathrm{~B} \cdot$ Text $)$

Dim y

$\mathrm{y}=\mathrm{B} / 2$

$\operatorname{Dim} \mathrm{N}$

$\mathrm{N}=\mathrm{y}-1$

Dim Tr

$\operatorname{Tr}=\operatorname{Val}(\operatorname{txt} \operatorname{Tr}$. Text $)$

Dim Tm

$\mathrm{Tm}=\operatorname{Val}(\mathrm{txtTm} \cdot \mathrm{Text})$

Dim Tb

$\mathrm{Tb}=\mathrm{Val}(\mathrm{txtTb}$. Text $)$

Dim Tmean

Tmean $=(\mathrm{Tr}+\mathrm{Tm}+\mathrm{Tb}) / 3$

Dim Vc

$\mathrm{Vc}=3.14 *(\mathrm{x} * \mathrm{y}-\mathrm{M} * \mathrm{~N}) * \operatorname{Tr}+3.14 * \mathrm{M} * \mathrm{~N} *$ Tmean

txtVc.Text $=\operatorname{Str}(\mathrm{Vc})$

Dim Ac

$\mathrm{Ac}=2 * 3.14 * \mathrm{x} * \mathrm{y}+2 * 3.14 *$ Tmean $*\left(\left(\mathrm{x}^{\wedge} 2+\mathrm{y}^{\wedge} 2\right) / 2\right)^{\wedge} 0.5$

txtAc. $\operatorname{Text}=\operatorname{Str}(\mathrm{Ac})$

End Sub

Private Sub cmdClear_Click()

txt2A.Text = ""

txt2B.Text $=" "$

txtTr.Text $=" "$

txtTm.Text = ""

txtTb.Text $=" "$

txtVc.Text $=" "$

txtAc.Text = ""

End Sub

Private Sub mnuhelp_Click()

MsgBox "In the corresponding text boxes enter lenght of the seed (L), Width of the seed (W), thicknesses values of narrow end (T1), middle of the seed (T2) and broad end then click calculate. ", vbOKOnly, "Help" End Sub 
PROCESS ENGINEERING

الملخص العربحى

الشكل الهندسى و القوة التلازمة لكسر

بذرة البطيخ (Colocynthis citrullus)

محمود أحمد مسلم**، أشرف كامل زعلوك* و رأفت على وربى**

يهدف هذا البحث الى در اسة الشكل الهندسى للب البطيخ (Colocynthis citrullus) و القوة اللازمة لفتق هذا اللب تحت نسب مختلفة من رطوبـة البذرة. اعتبرت البذرة في معظم كتلتها

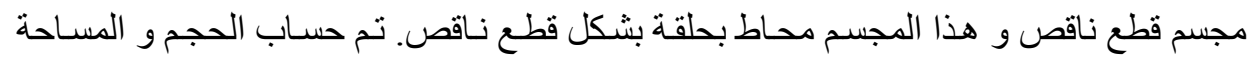

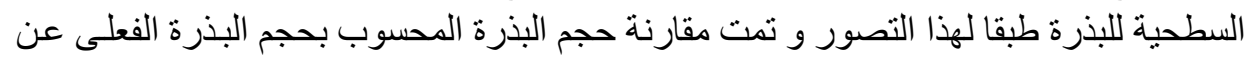

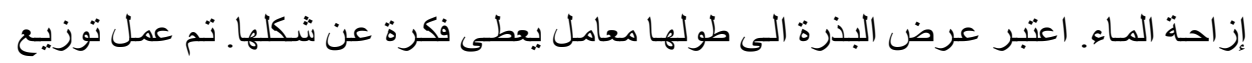

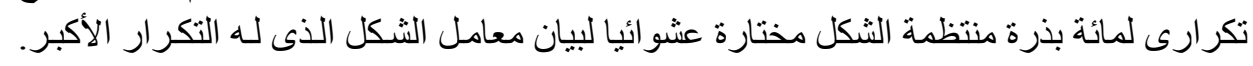

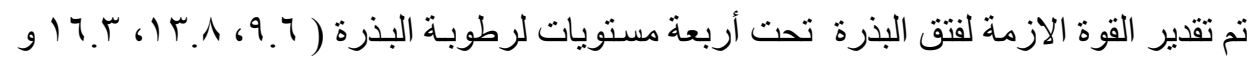

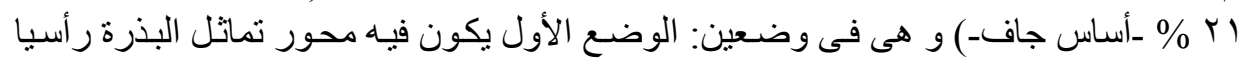

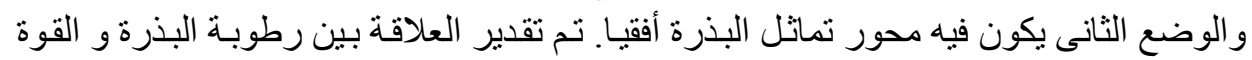
اللازمة للفتق فى الحالتين. انتهت الدر اسة إلى الآتى:

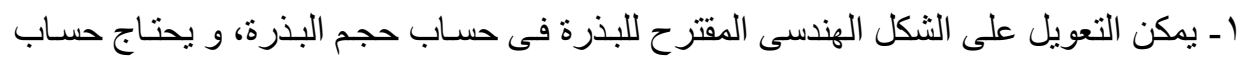

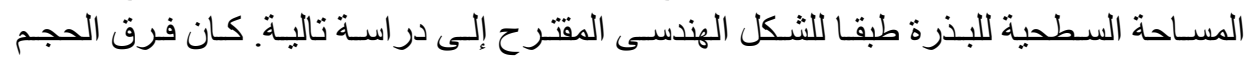

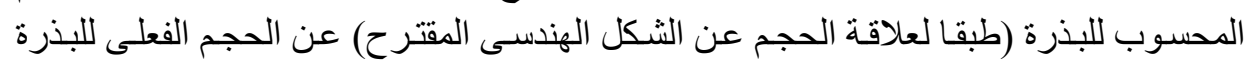
منسوبا لحجم البذرة الفعلى 9. \% \%

ז- بين هذا البحث أنه ربما أن أكبر تكر ار لمعامل شكل البذور يكون لمدى معامل الثكل إلى

"ـ- بينت الدر اسة أنه، فى حدود مدى رطوبة البذور المستخدم، فإن القوة اللازمة لفتق البذرة تقل

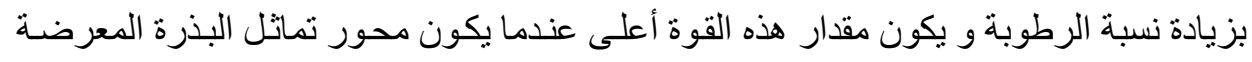

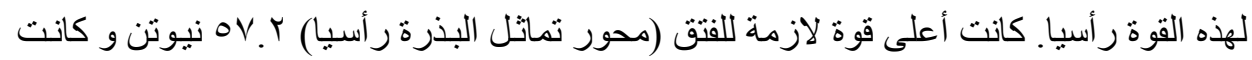

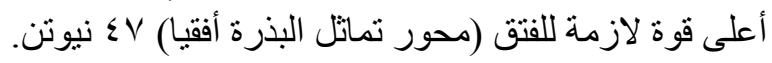

* أستاذ مساعد ـ قسم الهندسة الزراعية ــ كلية الزراعة ـ ـ جامعة الأزهر ـ القاهرة.

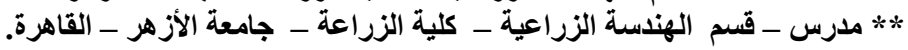

